\section{EL OTRO ROSTRO \\ DE LA MODERNIDAD: SOCIALISTAS Y CIENCIA ESOTÉRICA (1890-1930) \\ DORA BARRANCOS}

Dora Barrancos es Profesora Consulta de la UBA e Investigadora del CONICET.

e-mail:dora1508@aol.com

\section{Resumen}

El artículo aborda las relaciones que algunos socialistas mantuvieron con la teosofía, la escuela religiosa creada por la rusa Helena Blavatsky en la segunda mitad de siglo XIX. Esta corriente asimiló en buena medida las tesis del evolucionismo ya que sus tesis fundamentales se referían a la evolución superior a que podía acceder la humanidad. Se trató de un movimiento que reunió tanto a personas con una identidad religiosa, como a librepensadores y socialistas, y no faltaron numerosas mujeres. La ex fabiana Anne Besant sucedió a Bralavsky en la conducción del movimiento. En la Argentina, tres importantes socialistas de la primera fase, Alfredo Palacios, Leopoldo Lugones y José Ingenieros, adhirieron a la teosofía. El artículo examina especialmente sus posiciones teósofas a través de algunos escritos. Se concluye que el propio vértigo de la modernidad pudo llevar a los espíritus laicos a refugiarse en una doctrina que reunía la fe en la trascendencia junto con el crédito en la ciencia.
Este trabajo fue realizado hace mucho tiempo sin que la autora se decidiera a publicarlo. Ricardo Falcón conocía su existencia y algunas veces abordó con la autora la experiencia híbrida de razón y fe, las tensiones entre creencia y ciencia, que a menudo exhibieron quienes actuaron en nombre del proletariado. El texto ha sido remozado en homenaje a su memoria. Dora Barrancos agradece profundamente la colaboración de la Sociedad Teosófica Argentina y un especial reconocimiento a Bernardo Ruisoto, Cecilia Luvecce, Bernardo Nante y Nicolás Iñigo Carrera.

\section{Summary}

This article focuses on the relationships that some socialists maintained with theosophy, the religious school founded by Helena Blavatsky in the second half of the nineteenth century. This trend largely assimilated the theory of evolution given that its basic thesis referred to the higher evolution that humanity could access. It was a movement that gathered people with a religious identity, as much as freethinkers and socialists, and there were many women. The former Fabian Anne Besant succeeded in driving the movement. In Argentina, three important socialists of the first phase, Alfredo Palacios, Leopoldo Lugones and José Ingenieros, joined the Theosophy. The article examines in particular their theosophical positions through some writings. It is concluded that the vertigo of modernity itself was able to impulse lay spirits to take refuge in a doctrine that combined faith in transcendence with trust in science. 